\title{
MANAGEMENT
}

Received:

17 May, 2019

1st Revision:

12 June, 2019

Accepted:

15 June, 2019
UDC: 811.11:378.147:004.738

DOI https://doi.org/10.26661/2522-1566/2019-2/08-06

*Corresponding author email: olga_judina@ukr.net

OLGA YUDINA, PhD in Pedagogical Sciences, associate professor, Assistant Professor of the Department of Business Communication, Zaporizhzhya National University, Zaporizhzhya, Ukraine, ORCID ID: https://orcid.org/0000-0001-5400-7695

YANA DYBCHYNSKA, PhD in Linguistics, associate professor, Assistant Professor of the Department of Business Communication, Zaporizhzhya National University, Zaporizhzhya, Ukraine, ORCID ID: https://orcid.org/0000-0002-0992-7326

\section{MODEL OF INTEGRATED TEACHING MANAGEMENT CORE COURSES IN A FOREIGN LANGUAGE USING ICT}

Abstract. The paper purpose is to reveal the problem of future managers teaching and to describe the developed model of the integrated teaching of management core courses and foreign languages using ICT. The following theoretical and empiric methods have been used in the research: critical analysis of resources, current programs, education regulations, manuals; method of observation, questioning of students and professors to reveal their attitude to different aspects of training for business communication in a foreign language at the higher school, systematic and synthesis methods, education experiment. The object of the study is the process of integrated teaching of professional management disciplines in English using ICT. The subject of the study is the technology of integrated building of professional and foreign language communicative competences using ICT. The topicality of our research is grounded on the urgency of resolving the above mentioned contradictions and the need in investigations dedicated to the implementation of ICT based integrated learning into the management degree program. The practical importance of using ICT in education is providing autonomy, mobilizing students' learning abilities, creating conditions for individual learning and developing active position in learning activity. Using ICT in teaching subjects in English opens new methodological perspectives for developing both degree and subject programs for future managers. The analysis and comparison with the results of contemporary researches in the field of integrated learning using ICT and the own teaching experience at higher education institution prove the necessity of interactivity of the teaching process to provide communicative interrelation of all participants, self-control and self-correction. The second important characteristic of teaching disciplines in English using ICT is their technical characteristics and didactic opportunities for lectures, seminars, practical classes and individual work. The research has allowed generalizing the experience of implementation of contemporary innovative technologies in the integrated teaching of core courses and foreign languages. The use of ICT in didactic materials provides great opportunities for all participants of the education process, consequently leading to education quality improvement. The developed integrated model of the course programs "Corporate Social Responsibility" and "English for Professional Purposes" using ICT has proved the synergy effect allowing the effective acquisition of professional information on the one hand and the development of both professional and foreign language skills on the other hand, what ensures building the professional competence as a whole. The effectiveness of the model was experimentally proved after the processing of statistical data 
Yudina, O. and Dybchinska, Ya. (2019). "Model of integrated teaching management core courses in a foreign language using ICT", Management and entrepreneurship: trends of development, 2 (08), pp. 68-76. doi: https://doi.org/10.26661/2522-1566/2019-2/08-06

obtained in the course of the experiment. Considering the overall positive result of our experience we believe that negative factors are to be given a profound research and thorough analysis. In general efficient ICT using requires not only great efforts of the faculty in avoiding the negative factors but the development of the brand new complex approach to the ICT environment. As a conclusion the implementation perspectives of innovative technologies in the professionally training process of future managers are substantiated. The paper provides opportunities of developing the technology of integrated building of professional and foreign language competences using ICT. Such knowledge will help to improve the process of managers' professional training in Ukrainian higher schools.

Keywords: Information and Communication Technologies, Professional Competence, Foreign Language Communicative Competence, Integrated Teaching Model

JEL Classification: A22, D 83, I21, O32

\section{INTRODUCTION}

The tendency of scholars' raising interest in the problem of implementation of Information and Communication Technology (ICT) in education process is observed in Ukraine under the development of information society and the modernization of the system of higher education. The principles of unification of the system of higher education in Europe and the approximation of the curricula to the unified international standards put forward the task of the professional training of specialists with the level of the foreign language competence that corresponds to the world standards and provides the opportunity to use a foreign language in their further professional activity for creating business contacts and building cooperation with specialists in the related spheres.

The requirements of the modern education to train the multilateral personality demand the rationalization of the process of both professional and language teaching of future managers on the basis of efficient innovative educational technologies stipulated by the contemporary requirements and real conditions of the higher school. The solution to these problems is possible within the framework of the system of integrated teaching of major disciplines and a foreign language using ICT at the lessons and for individual work.

\section{LITERATURE REVIEW}

The authors of modern researches S. Bajt (2011), W. Fong (2011), J. Fu (2013), R. Hernandez (2017), J. Katz (2013), T. Koval (2009), K. Ratheeswari (2018) and others have investigated different aspects of the problem of ICT implementation in education. E-learning technologies were studied by A. Andreev (2008), O. Bigych, M. Voloshynova and O. Matsneva (2009), R. Clark and R. Mayer (2011), D. Rösler (2007), M. Gaebel, V. Kupriyanova, R. Morais and E. Colucci (2014) and others. Communicative characteristics of informational media of communication have been considered by V. Dronov (2009), M. Yevdokimova (2004), S. Zenkina (2007), O. Pankratova (2012), I. Rozina (2005), T. Lawrence (2010) and others. The problems of adult learners and technology were touched upon in the works of L. J. Ausburn (2004), M. Johnson (2011) and others. The methodological grounds of ICT using for building the foreign language communicative competence in different types of speech activity were analysed by the Ukrainian researchers $\mathrm{S}$. Nikolayeva, Yu. Brytan, Ya. Dyachkova, N. Mayer, Ya. Krapchatova and V. Chernysh (2015) and others.

The analysis of modern researches and publications conducted in this field, the regulations and teaching materials, as well as observations of the teaching process in the higher school have allowed stating a number of contradictions: 
between the requirements of the society to the quality of professional education in management, the needs of higher educational institutions in scientifically and methodologically grounded materials for the efficient educational process using ICT on the one hand and the lack of the developed materials for teaching core courses and foreign language on the other hand; between the new requirements of educational programs to build competences within the amount of ECTS on the one hand and limited amount of classroom hours for every discipline on the other hand.

The topicality of our research is grounded on the urgency of resolving the above mentioned contradictions and the need in investigations dedicated to the implementation of ICT based integrated learning into the management degree program. The practical importance of using ICT in education is providing autonomy, mobilizing students' learning abilities, creating conditions for individual learning and developing active position in learning activity. Using ICT in teaching subjects in English opens new methodological perspectives for developing both degree and subject programs for future managers.

The aim of this article is to describe the organizational and educational conditions of integrated building of professional and foreign language competences within the framework of the developed model of the integrated teaching of management core courses and foreign languages using ICT.

\section{RESULT AND DISCUSSION}

The necessity of creation of organizational and educational conditions of teaching competitive specialists for highly technological and innovative development of the country and achievement of the results according to the educational professional program is determined by the law of Ukraine "On Higher Education". The investigation of the didactic potential of the Internet resources and the design of the mechanism of effective implementation of innovative educational methods and technologies in the bachelor and master programs are stipulated by the social demand and current regulations issued by the Ministry of Education and Science of Ukraine, that is by the requirements of the Licensing of educational activity in the sphere of higher education (the Decree of the Cabinet of Ministers dated December 30, 2015).

The solution of the practical tasks of the contemporary education is connected with implementation of modern innovative educational technologies, development of new principles, strategies and methods of teaching within the framework of integrated learning. These novelties are to be applied when teaching professional subjects and foreign language and will provide effective learning process aimed at acquiring the necessary competencies.

The development of the education process at higher school in the conditions of information society is connected with using of virtual environment (Nikolayeva, Mayer, Chernysh et al., 2015). The advantage of education organization using ICT environment according to M. Nimatulayev is the opportunity to perform the approach based on personally individual activity, namely creating the conditions for self-learning and individual learning process of every student (2012). I. Rozina states that learning using ICT environment is the brand new paradigm based on the functional effectiveness of ICT and build on the e-learning culture comprising the positions of an e-learner and an e-teacher (2005). Following the opinion of S. Zenkina we consider the ICT environment as a complex of electronic methods of teaching and communicating using of which allows performing the gradual learning activity that builds both professional and foreign language competences of a student (2007). According to V. Dronov the modern ICT environment is to meet the requirements of students, to be able to adapt to different educational situations and to possess the corresponding content and structure (2009).

The analysis and comparison with the results of contemporary researches in the field of integrated learning using ICT and the own teaching experience at higher education institution prove the necessity of interactivity of the teaching process to provide communicative interrelation of all participants as well as self-control and self-correction. The second important characteristic of 
Yudina, O. and Dybchinska, Ya. (2019). "Model of integrated teaching management core courses in a foreign language using ICT", Management and entrepreneurship: trends of development, 2 (08), pp. 68-76. doi: https://doi.org/10.26661/2522-1566/2019-2/08-06

teaching disciplines in English using ICT is their technical characteristics and didactic opportunities for lectures, seminars, practical classes and individual work. The use of ICT in teaching subjects in English opens new methodological perspectives of developing degree and subject programs for future managers. That is why we have generalized the experience and implemented the following modern educational and information communication technologies:

The foreign language integrated learning technology (creation of content and information interdisciplinary connections to build the foreign language competence, the technology of integrated building of professional and language competences, etc.);

The Internet oriented teaching technologies (education programs, presented in the Internet, online tests, on-line courses, LMS Moodle);

Professional activity oriented technologies (projects, group work facilitation, professional business game, problem solving, etc);

Information education technologies (search engines, educational Internet portals and services Web 2.0, education webinars, electronic manuals, computer educational programs, audiovisual and multimedia materials, etc);

Case technology based on using the cases in audiovisual and multimedia sources in independent study.

The use of m-learning environment along with other IC technologies is used for the organization of educational process that does not depend on certain place and time. PDAs allow students to access educational resources, to connect with other students, to create educational content in class and outside the University.

Studying the business communication in a foreign language with the help of online libraries and dictionaries makes grasping and increasing the knowledge easy for the future managers. Nonetheless, electronic educational technology, also called e-learning, has become an important part of society today, comprising an extensive array of digitization approaches, components and delivery methods. For example, m-learning emphasizes mobility, but is otherwise indistinguishable from educational technology.

The informational educational resources provide students with the access to the up-to-date professional information through foreign resources, the opportunity to improve their knowledge of foreign language and to prepare the presentation of their research. Using of different tools of $\mathrm{m}$ learning environment allows the access to the up-to-date information in a foreign language during classes and individual activities, the performance of storing, exchange and spread of authentic linguistic and professional information (Nikolayeva, Mayer, Chernysh et al., 2015).

The Ukrainian psychologists and educators consider that the influence of informational technologies on personal development is impossible to classify as definitely positive or negative (Information communication technologies of teaching..., 2011). On the one hand the Internet addiction causes negative transformations of the personality, but on the other hand it promotes the opportunities for the development of I-concept and the motivational sphere in general. The lack of motivation results in the attention switch to games, social media, music and other entertainments. The teacher, using the ICT, can easily slip from educational to visual teaching methods.

Putting an accent on didactic and methodological advantages of ICT use in the process of integrated building of professional and foreign language communicative competence we agree with the opinion of the scholars (Nikolayeva, Mayer, Chernysh, V. et al., 2015) who accept the existence of disadvantages in the use of the Internet technologies:

the possibility to obtain the outdated or unprofessional information;

the author's bias as to the issues presented in hypertexts;

the limited amount of free issues of professional editions.

Our preliminary list of negative effects was based on the researches, conducted by other scholars (El Mansour and Mupinga, 2007). This list contains the following items: 
1. Issues connected with the contents of the educational process: literacy and numeracy issues; work with information.

2. Issues connected with the methodology of education: student's distraction during classes; low motivation due to lack of computer skills; assessment tools; feedback tools; support of lectures; interaction in the educational process.

3. Issues connected with the context of the educational process: digital divide; technical problems in class; teacher's competence in ICT.

The researches in the problem of the provision of interactivity of educational means based on ICT (Bajt 2011; Lawrence 2010; Nikolayeva, Mayer, Chernysh et al., 2015) define the following indicators of interactivity:

1. Non-linear access to educational information.

2. Efficiency of feedback in both directions.

3. Communication among the subjects of educational process.

4. Adaptation of the education system to student' individual needs.

5. Implementation of the educational strategies in the individual activity.

The model of integrated teaching professional courses in English using ICT was created on the basis of the major course "Corporate Social Responsibility" (taught in English) and the course "English for professional purposes" for the second year students of specialty "Management" of Zaporizhzhia National University considering the total amount of credits and hours according to the curriculum presented in Table 1. The use of ICT in the learning process was rational designed depending on the type of a lesson (lectures, seminars, practical classes or individual work), the specifics of the discipline, the goals and objectives of the teaching process.

Table 1

The integrated teaching model using ICT

\begin{tabular}{|c|c|c|c|c|c|c|c|c|c|c|}
\hline \multirow[b]{2}{*}{ Course } & \multicolumn{10}{|c|}{ Information communication technologies } \\
\hline & 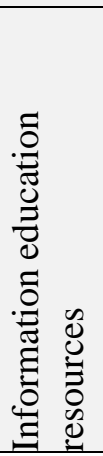 & 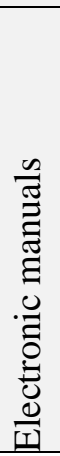 & 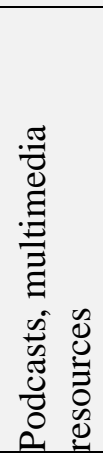 & 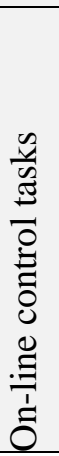 & 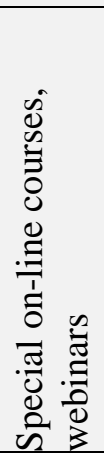 & 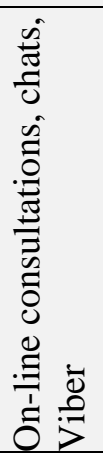 & 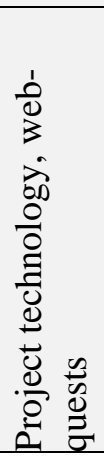 & 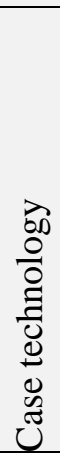 & 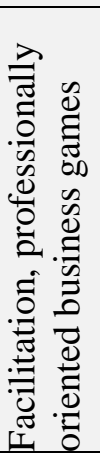 & $\begin{array}{l}\frac{0}{\delta} \\
\frac{8}{2} \\
\sum_{J}^{\mathscr{D}}\end{array}$ \\
\hline $\begin{array}{l}\text { Corporate } \\
\text { Social } \\
\text { Responsibility } \\
\text { (in English) }\end{array}$ & + & + & + & + & + & + & + & + & + & + \\
\hline $\begin{array}{l}\text { English for } \\
\text { professional } \\
\text { purposes }\end{array}$ & + & & + & + & & + & + & + & + & + \\
\hline
\end{tabular}

The effectiveness of the model was experimentally proved after the processing of statistical data obtained in the course of the experiment (Yudina, Shavkun, Dybchynska and Bukharina, 2018). The results of the control after the experiment proved that the students of all four groups achieved and excelled the minimum enough level of competences. The developed integrated model of the course programs "Corporate Social Responsibility" and "English for Professional Purposes" using ICT has 
Yudina, O. and Dybchinska, Ya. (2019). "Model of integrated teaching management core courses in a foreign language using ICT", Management and entrepreneurship: trends of development, 2 (08), pp. 68-76. doi: https://doi.org/10.26661/2522-1566/2019-2/08-06

proved the synergy effect allowing the effective acquisition of professional information on the one hand and the development of both professional and foreign language skills on the other hand, what ensures building the professional competence as a whole.

The use of podcasts helped the development of listening and speaking skills, but its influence on reading and writing skills is relatively insignificant. This resource was very useful for improvement of the aural perception of the English speech. Social networks were used by professors and students to create educationally oriented groups. This tool was used not only for communication but also for educational purposes; this allowed the improvement of reading and writing skills as well as the ability of working in a group. The Viber application for smartphones on platforms Android, iOS, Windows Phone was useful for the improvement of all types of speech skills. Project technology, web-quests, case technology, facilitation, professionally oriented business games were used in the integrated teaching of core disciplines and the English language.

The results of web-quests were realized through a multimedia presentation the function of which is to present the students' research activity. Participation in web-quests developed the ability to think independently, to solve professionally important problems, to forecast the results and possible consequences of different scenarios, to determine cause - effect relations. M-learning environment involved in the model includes both university and personal learning environment both for professors and students.

\section{CONCLUSION}

The research attempted in a comprehensive way to solve the problem of the rationalization of the process of both professional and language training of future managers on the basis of efficient innovative educational technologies stipulated by the contemporary requirements and real conditions of the higher school education. The use of ICT in didactic materials provides great opportunities for all participants of the education process, consequently leading to education quality improvement. The results of the experiment can be used in developing of the recommendations as to using ICT in integrated teaching of core courses and a foreign language to future managers.

\section{REFERENCES}

Andreyev, A. (2008). Practice of electronic teaching using Moodle, Taganrog: TTI SFU, Russia, (in Russian).

Ausburn, L. J. (2004). "Course design elements most valued by adult learners in blended online education environments: An American perspective", Educational Media International, vol.41(4), Oklahoma State University, USA, [Online], available at: https://pdfs.semanticscholar.org/44ef/bf571bce7ed7e4a61ef 3ac15107986551f08.pdf (Accessed 10 May 2019).

Bajt, S. K. (2011). "Web 2.0 technologies: Applications for community colleges", New Directions for Community Colleges, [Online], Issue 154, available at: https://onlinelibrary.wiley.com/doi/abs/10.1002/cc.446 (Accessed 10 May 2019).

Bigych, O.B., Voloshinova, M.M. and Matsneva, O.A. (2012). Electronic means of teaching foreign languages to students: The experience of development and approbation, Publishing house of KNLU, Kyiv, Ukraine, (in Ukrainian).

Clark, R. and Mayer, R. E. (2011). E-learning and the science of instruction: proven guidelines for consumers and designers of multimedia learning [2nd edition]. San Francisco: Pfeiffer, XVI, 476 p. doi:10.1002/9781118255971

Dronov, V. (2009). "Information and education environment of the XXl century", Vestnik obrazovaniya, vol. 15 , pp. 44-52, (in Russian). 
El Mansour, B. and Mupinga, D.M. (2007). "Students' positive and negative experiences in hybrid and online classes". College Student Journal, 41 (1) 242-248, [Online], available at: https://d21.pdx.edu/d21/lor/viewer/ viewFile.d2lfile/6605/824/modules/2-planning/3-teachingonline/1-online-learning-facilitation/ articles/Mansour_and_Mupinga.pdf (Accessed 7 May 2019).

Fong, W.W. (2011). "From Web 2.0 to Classroom 3.0.” In: Kwan R., Fong J., Kwok L., Lam J. (eds) Hybrid Learning. ICHL 2011. Lecture Notes in Computer Science, vol 6837. Springer, Berlin, Heidelberg. doi: 10.1007/978-3-642-22763-9_28

Fu, J., Sh. (2013). "ICT in Education: A Critical Literature Review and Its Implications". International Journal of Education and Development using Information and Communication Technology (IJEDICT), 9 (1), [Online], available at: https://files.eric.ed.gov/fulltext/EJ1182651.pdf (Accessed 10 May 2019).

Gaebel, M., Kupriyanova, V., Morais, R. and Colucci, E. (2014). E-learning in European Higher Education Institutions, [Online], available at: https://eua.eu/downloads/publications/elearning\%20in\%20uropean\%20higher

$\% 20$ education\%20institutions\%20results\%20of\%20a\%20mapping\%20survey.pdf (Accessed 15 May 2019).

Hernandez, R., M. (2017). "Impact of ICT on Education": Challenges and Perspectives Propósitos y Representaciones Ene. - Jun. 2017, [Online], Vol. 5, № 1: pp. 325-347, available at: http://dx.doi.org/10.20511/pyr2017.v5n1.149 (Accessed 12 May 2019).

Information communication technologies of teaching: psychological, pedagogical and didactic aspects of implementation : proceedings of scientific and practical Internet conference, Kirovograd, 2011, [Online], available at: http://timso.koippo.kr.ua/blogs/index.php/Internetkonferencia_(in Ukrainian) (Accessed 10 May 2019).

Johnson, M. (2011). "Adult learners and technology: how to deliver effective instructions and overcome barriers to learning", [Online], available at: http://www.umsl.edu/ wilmarthp/modlalinks-2011/Adult-Learners-And-Technology.pdf (Accessed 15 May 2019).

Katz, J. (2013). "The Three-Block Model of Universal Design for Learning Implementation in a High School". [JEAP, p.141, [Online], available at: https://journalhosting.ucalgary.ca/index.php/cjeap/article/view/42841/30698 (Accessed 12 May 2019).

Koval, T., Sysoyeva, S. and Suschenko, L. (2009). Teaching higher school educators: informational technologies in education, Editing department of KNLU, Kyiv, Ukraine, (in Ukrainian).

Lawrence, T. (2010). "ICTs for Modern Educational and Instructional Advancement: New Approaches to Teaching", NY: Hershey, New York, USA.

Nikolayeva, S., Mayer, N., Chernysh, V. et al. (2015). "Modern technologies of teaching foreign languages and cultures in secondary and higher educational institutions", Lenvit, Kyiv, Ukraine, (in Ukrainian).

Nimatulayev, M. (2012). "The need of modern design information educational environment based on didactic opportunities of web-technology", Standarty i monitoring v obrazovanii, vol. 3, pp. 27-29, (in Russian).

Pankratova, O. (2012). "Realization of the competence approach in forming an information educational environment in higher school (by the example of the Stavropol state university)", Standarty i monitoring v obrazovanii 3, pp. 42-45, Russia, (in Russian).

Ratheeswari, K. (2018). Information Communication Technology in Education. May 2018. doi: 10.21839/jaar.2018.v3iS1.169

Rösler, D. (2007), E-Learning Fremdsprachen: eine kritische Einführung, Stauffenberg Verlag, 246 S. doi: 10.1515/infodaf-2008-2-384 
Yudina, O. and Dybchinska, Ya. (2019). "Model of integrated teaching management core courses in a foreign language using ICT", Management and entrepreneurship: trends of development, 2 (08), pp. 68-76. doi: https://doi.org/10.26661/2522-1566/2019-2/08-06

Rozina, I. (2005). "Pedagogical computer-mediated communication as an applied sphere of communication researches", Educational Technology \& Society, vol. 8, Issue 2, pp. 257-264, Russia, (in Russian).

The Law of Ukraine (September 5, 2017) No 2145-VIII "On higher education", [Online], available at: http://www.osvita-konotop.gov.ua/zakon-ukra\%D1\%97ni-vid-05-09-2017-2145-viii-proosvitu.html (Accessed 10 May 2019).

Yevdokimova, M. (2004). Problems of theory and practice of ICT in teaching foreign languages. MIET, Moscow, Russia, (in Russian).

Yudina, O., Shavkun, I., Dybchynska, Ya. and Bukharina, L. (2018). "ICT Using in Integrated Teaching Management Core Courses in a Foreign Language", ICT in Education, Research and Industrial Applications. Integration, Harmonization and Knowledge Transfer CEUR Workshop Proceedings, [Online], available at: http://ceur-ws.org/Vol-2105/ (Accessed 15 May 2019).

Zenkina, S. (2007). Pedagogical basics of orientation of ICT to new learning results, Moscow, Russia, (in Russian).

\section{МОДЕЛЬ ІНТЕГРОВАНОГО НАВЧАННЯ ФАХОВИХ ДИСЦИПЛІН 3 МЕНЕДЖМЕНТУ ІНОЗЕМНОЮ МОВОЮ 3 ВИКОРИСТАННЯМ ІКТ}

ЮДІНА ОЛЬГА ВОЛОДИМИРІВНА, кандидат педагогічних наук, дочент, доцент кафедри ділової комунікації, Запорізький національний університет, м. Запоріжжя

ДИБЧИНСЬКА ЯНА СТАНІСЛАВІВНА, кандидат філологічних наук, дочент, дочент кафедри ділової комунікації, Запорізький національний університет, м. Запоріжжя

Актуальність теми дослідження обумовлена потребою сучасного суспільства у кваліфікованих менеджерах та необхідністю забезпечення ефективної організації процесу фахової та іншомовної підготовки майбутніх фахівців на основі новітніх ефективних педагогічних технологій. Предметом дослідження є методика інтегрованого навчання фахових дисциплін 3 менеджменту англійською мовою 3 використанням інформаційнокомунікаційних технологій. Мета - вивчення організаційно-педагогічних умов інтегрованого формування фахової та іншомовної комунікативної компетентностей у майбутніх менеджерів у рамках моделі навчання дисциплін професійної та іншомовної підготовки із застосуванням сучасних інформаційно-комунікаційних технологій. Використання IКТ у викладанні предметів англійською мовою відкриває нові методологічні перспективи для розробки як дипломних, так і предметних програм для майбутніх менеджерів. Аналіз і порівняння 3 результатами сучасних досліджень в області інтегрованого навчання 3 використанням ІКТ та власного педагогічного досвіду в вузі доводять необхідність інтерактивності навчального процесу для забезпечення комунікативного взаємозв'язку всіх учасників. Іншою важливою характеристикою викладання дисциплін англійською мовою 3 використанням IКТ $є$ їх технічні характеристики і дидактичні можливості для лекцій, семінарів, практичних занять та індивідуальної роботи. Дослідження дозволило узагальнити досвід впровадження сучасних інноваційних технологій в комплексне викладання основних курсів і іноземних мов. Наукова значущість роботи полягає в дослідженні механізмів застосування інформаційно-комунікаційних технологій в умовах інтегрованого навчання фахових дисциплін іноземною мовою. Практичне значення одержаних результатів дослідження полягає у створенні моделі інтегрованого навчання фахових дисциплін 3 менеджменту англійською мовою 3 використанням інформаційно-комунікаційних технологій.

Ключові слова: інформаційно-комунікаційні технології, фахова компетентність, іншомовна комунікативна компетентність, модель інтегрованого навчання. 


\section{МОДЕЛЬ ИНТЕГРИРОВАННОГО ОБУЧЕНИЯ ПРОФЕССИОНАЛЬНЫМ ДИСЦИПЛИНАМ ПО МЕНЕДЖМЕНТУ НА ИНОСТРАННОМ ЯЗЫКЕ С ИСПОЛЬЗОВАНИЕМ ИКТ}

ЮДИНА ОЛЬГА ВЛАДИМИРОВНА, кандидат педагогических наук, дочент, дочент кафедры деловой коммуникации, Запорожский национальный университет, г.Запорожье. ДЫБЧИНСКАЯ ЯНА СТАНИСЛАВОВНА, кандидат филологических наук, доиент, дочент кафедры деловой коммуникаџии, Запорожский наџиональный университет, 2.3апорожье.

Актуальность темы исследования обусловлена потребностью современного общества в квалифицированных менеджерах и необходимостью обеспечения эффективной организации процесса профессиональной и иноязычной подготовки будущих специалистов на основе новейших педагогических технологий. Предметом исследования является методика интегрированного обучения профессиональным дисциплинам по менеджменту на английском языке с использованием информационно-коммуникационных технологий. Цель - изучение организационно-педагогических условий интегрированного формирования профессиональной и иноязычной коммуникативной компетентностей у будущих менеджеров в рамках модели обучения дисциплинам профессиональной и иноязычной подготовки с использованием современных информационно-коммуникационных технологий. Использование ИКТ в преподавании предметов на английском языке открывает новые методологические перспективы для разработки как дипломных, так и предметных программ для будущих менеджеров. Анализ и сравнение с результатами современных исследований в области интегрированного обучения с использованием ИКТ и собственного педагогического опыта в вузе доказывают необходимость интерактивности учебного процесса для обеспечения коммуникативной взаимосвязи всех участников. Второй важной характеристикой преподавания дисциплин на английском языке с использованием ИКТ является их технические характеристики и дидактические возможности для лекций, семинаров, практических занятий и индивидуальной работы. Исследование позволило обобщить опыт внедрения современных инновационных технологий в комплексное преподавание основных курсов и иностранных языков. Научная ценность работы заключается в исследовании механизмов использования информационно-коммуникационных технологий в условиях интегрированного обучения профессиональным дисциплинам на иностранном языке. Практическое значение полученных результатов состоит в создании модели интегрированного обучения профессиональным дисциплинам на иностранном языке с использованием современных информационно-коммуникационных технологий.

Ключевые слова: информационно-коммуникационные технологии, профессиональная компетентность, иноязычная коммуникативная компетентность, модель интегрированного обучения. 